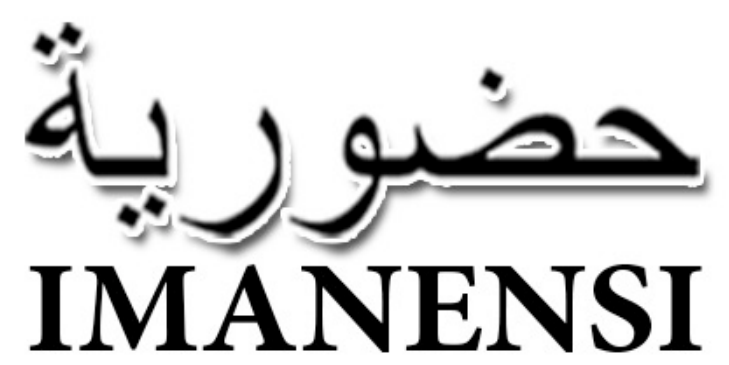

(Jurnal Ekonomi, Manajemen, dan Akuntansi Islam)

Vol 3, No 1, Maret 2018, Hlmn. 29-36

\title{
Kedudukan pajak dan zakat dalam kesejahtraan semesta
}

\author{
Mita Shoviatya, Irmayantib, Rofi'atul Maghfirohc \\ A,b,c Universitas Brawijaya Malang, Indonesia 65145 \\ 1*Irmayantii3059@gmail.com, mrofiatu10918@gmail.com
}

doi: 10.34202/imanensi.3.1.2018.29-36

\begin{abstract}
Abstrak
Perkembangan ekonomi kapitalis membentuk manusia sebagai homo ecoonomicus yang individualis mengesampingkan kesejahteraan semesta. Pajak yang menjadi pilar utama dalam perekonomian negara justru semakin memperparah kesenjangan ekonomi sehingga dalam artikel ini peneliti bertujuan mengkaji pajak yang berbasis pertumbuhan ekonomi dan zakat berbasis distribusi kekayaan dalam mensejahtrakan semesta. Metode penelitian kajian pustaka. Hasil penelitian ini adalah mengembalikan makna zakat sebagai sumber pendapatan utama negara Islam yang mengikis sifat ketamakan untuk mencapai rahmatan lil alamin.
\end{abstract}

Kata kunci: Zakat; Ekonomi Kapitalis; Kesejahteraan Semesta; Zakat.

\begin{abstract}
The development of capitalist economics shapes human beings as homo ecoonomicus, which individualists override universal wellbeing. Taxes which are the main pillars of the country's economy further aggravate the economy in this article reviewing taxes based on economic growth and zakat-based wealth distribution in the universe. Methods of literature review research. The results of this study are the return of the meaning of zakat as the main source of income of the Islamic State which erodes the nature of greed to achieve rahmatan lil alamin.
\end{abstract}

Keywords: Zakat; Economic Capitalist; Universal Well-being; Zakat

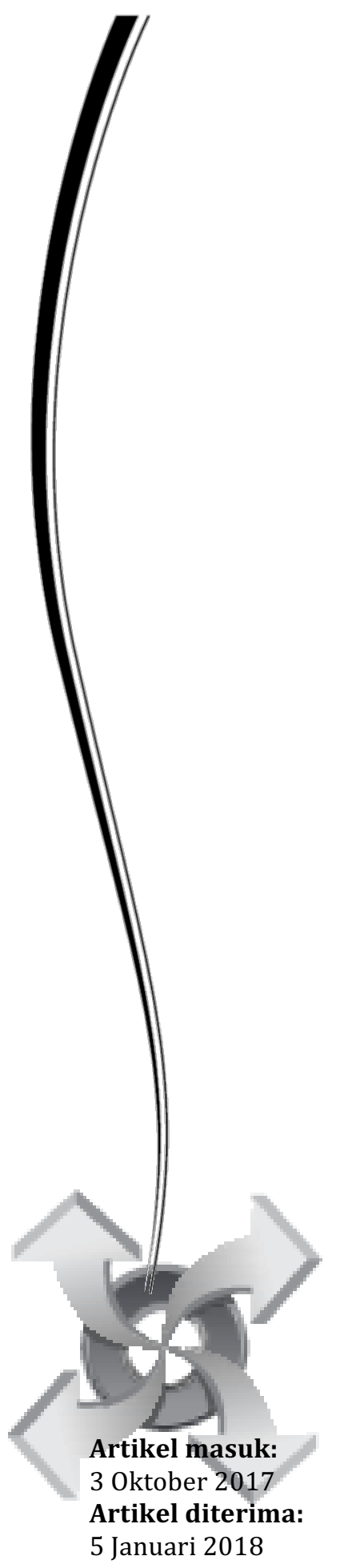

This is an open access article under the CC-BY-SA license. 
Konflik yang terjadi pada negara-negara saat perang dunia II dan munculnya perspektif humanisme barat membuka gerbang eksploitasi besar-besaran yang terjadi hampir di setiap negara. Humanisme barat memulai wacananya bahwa manusia selalu menentang para dewa yang mendominasi kekuasaan alam dengan cara menguasai dan menaklukan alam, sehingga dengan kebebasan yang dimilikinya menjadikannya sebagai penguasa alam (Adesy, 2016). Salah satu dampak dari humanisme barat juga munculnya gagasan tentang homo economicus atau manusia ekonomi, sehingga eksistensi manusia dan suatu negara pada akhirnya ditentukan seberapa banyak ia dapat mengeksploitasi sumber daya. Pertumbuhan ekonomi kemudian seolah menjadi tameng ekonomi kapitalis dalam membenarkan tindakan ketamakannya tersebut. Aspek moral dan sosial dibenarkan sepanjang berdampak positif dalam meningkatkan nilai ekonomi (Adesy, 2016). Dalam konteks Indonesia perubahan iklim demokrasi Indonesia sejak turunnya presiden Soeharto tahun 1998 membawa dampak pada demokrasi dan desentralisasi. Desentralisasi menjadi fasilitas pertumbuhan ekonomi yang digerakkan oleh sumber daya alam.

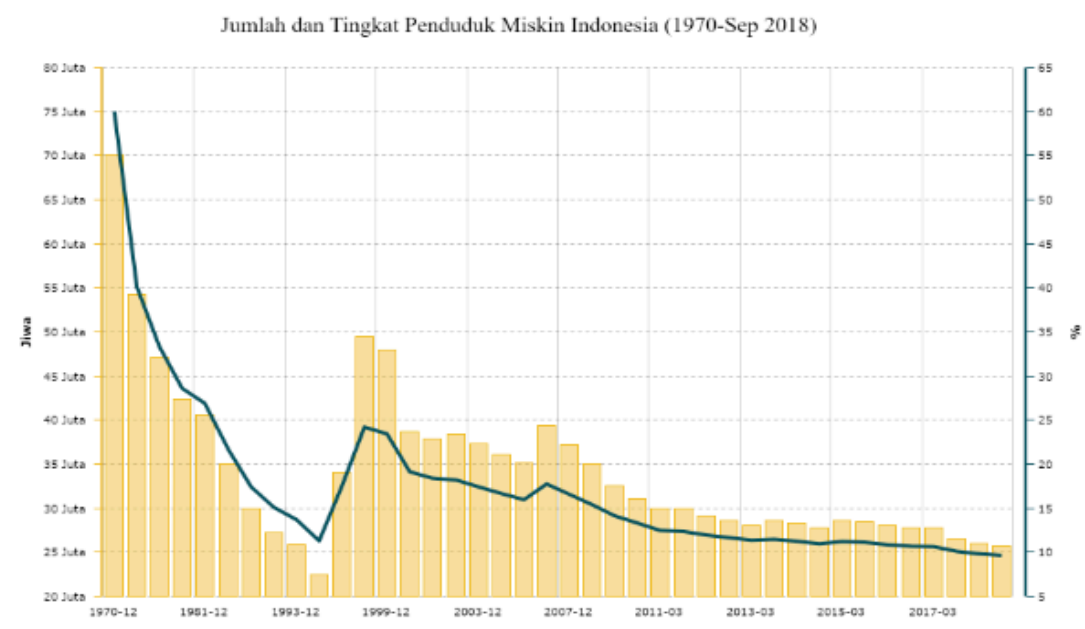

Sumber: databoks.co.id

Gambar 1. Jumlah dan tingkat penduduk miskin Indonesia (1970-September 2018).

Hal ini mengakibatkan perubahan lonjakan permintaan eksternal dari ekonomi yang sedang berkembang yaitu lonjakan sumber daya alam, pertama pada sektor pertambangan dan kedua pada sektor perkebunan. Pengambilan sumber daya alam khususnya di Indonesia seringkali dibarengi oleh kepentingan nasional yang fokus pada kebijakan distribusi manfaat ata kekayaan alam negara bagi generasi sekarang dan selanjutnya. Tercatat data kementerian keuangan realisasi sementara penerimaan Sumber Daya Alam pada tahun 2018 tumbuh 62,96\% menjadi 161,1 triliun. Selain itu upaya pemerintah juga meingkatkan pemasukan negara lewat pajak, realisasi penerimaan pajak januari 2019 mencapai Rp 89,8 triliun tumbuh $8,7 \%$ dibanding Januari 2018. Namun, penurunan tingkat kemiskinan selama terjadi lonjakan sumber daya alam memunculkan ketimpangan yang signifikan. Pada tahun 1970-an angka kemisikinan menyentuh 70 juta jiwa, tahun 1999-an angka kemiskinan menyentuh 50 juta jiwa sampai pada tahun 2017 angka kemiskinan menyentuhnya 26 juta jiwa. Artinya, pemerintah mulai tahun 1970 - $2017 \mathrm{mampu}$ menurunkan tangka kemiskinan 9,66\% (Gambar 1). Penurunan angka kemiskinan masih dianggap semu karena kebijakan instan yang dibuat oleh pemerintah berupa bantuan social seperti program Kartu Indonesia Pintar, bukan dari meningkatkan produktivitas masyarakat. 
Penurunan angka kemiskinan nyatanya tidak memberikan efek yang signifikan terhadap ketimpangan (Gambar 2). Misalkan pada tahun 2018, di Papua masih tercatat sebagai provinsi dengan angka kemikinan yang tertinggi di negara Indonesia yang mencapai $27,74 \%$ dari total populasi. Dibalik besarnya kekayaan alam tanah papua masih banyak kehidupan penduduk dibawah garis kemiskinan. Studi James Cust, Torfinn Harding dan Pierre Louis Vezina yang menganalisis pengaruh lonjakan minyak dan gas pada perusahaan manufaktur (Indonesia) menemukan, lonjakan minyak dan gas menuntun kepada keinaikan produksi perusahaan, gaji dan produktivitas karyawan. Kenyataannya daerah yang bergantung pada sektor minyak, gas, dan penambangan batu bara serta mineral cenderung memiliki tingkat kesejahteraan dan Pendidikan yang lebih rendah dibanding dengan daerah yang memiliki pendapatan sama namun tidak bergantung pada sumber daya.

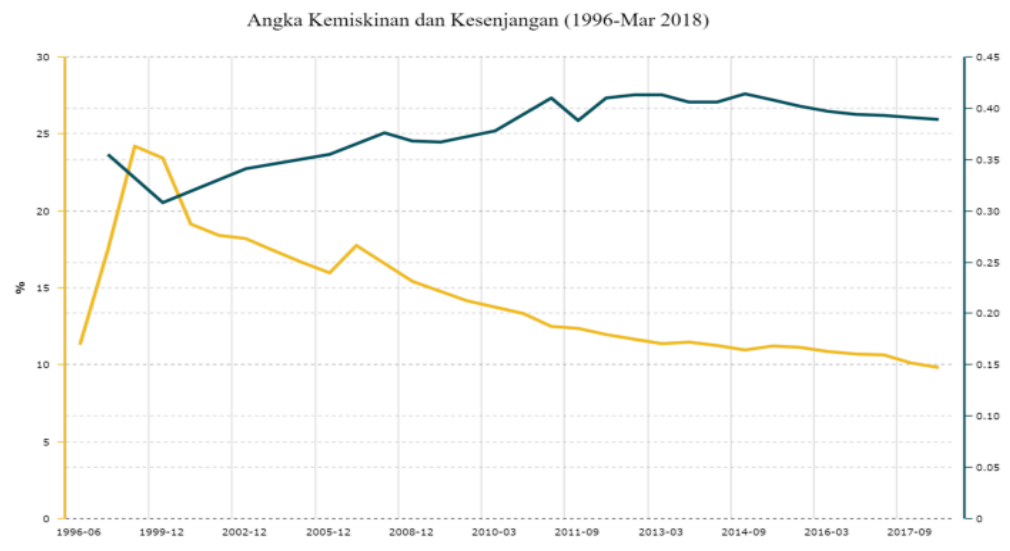

Sumber: databoks.co.id

Gambar 2. Angka kemiskinan dan kesenjangan (1996-Maret 2018).

Salah satu model penyelesaian ketimpangan yang terjadi adalah pemerataan pendapatan. Dalam islam pemerataan pendapatan ini dikenal sebagai zakat. menurut Qardhawai, 1999 dan Hafidhuddin, 2006, zakat bisa diartikan sebagai keberkahaan, pertumbuhan dan perkembangan, kesucian, keberasaan, dan terpuji. Selain itu zakat merupakan salah satu rukun Islam, hal ini menjadikan zakat sebagai acuan social yang wajib dikerjakan oleh umat muslim. Efek dari menunaikan zakat bagi ekonomi adalah memperkecil kesenjangan antar masyarakat sedangkan bagi adalah sebagai penyucian jiwa dari sifat kikir, tamak, egois karena harta yang dimiliki mengandung hak orang lain. Pengelolaan zakat dengan tepat mampu mengurangi kemiskinan.

Hal ini didukung oleh data yang diberikan Baznas pada bulan Maret 2019 garis kemiskinan pengalami penurunan. Jumlah kelompok miskin turun $28 \%$ setelah memperoleh dana zakat, sedangkan berdasarkan had kifayah, penururnan jumlah kelompok miskin adalah $36 \%$, jika diukur berdasarkan nisab beras maka penurunan $23 \%$ serta diukur berdasakan nishab emas makan penurunan jumlah kelompok miskin mencapai $26 \%$

Penelitian ini bertujuan untuk mengangkat zakat sebagai sumber utama negara dalam memberantas kemiskinan dan eksploitasi oleh sejumlah pihak. Pembahasan pertama dalam artikel ini adalah ketamakan yang dibentuk oleh kaum kapitalis yang berdampak pada eksploitasi sumber daya. Pembahasan kedua tentang hakikat manusia sebagai khalifah dan abdullah Allah untuk mengembalikan fitrah manusia yang mengemban amanah dari Allah. Dan pembahasan terakhir adalah diskurs tentang pajak dan zakat yang akan menunjukkan kelemahan pajak dalam mensejahtrakan masyarakat serta kelebihan zakat dalam mendistribusikan kekayaan yang kurang diekspos oleh suatu negara. Tujuan artikel ini mengangkat zakat sebagai 
topik utama dalam perekonomian negara adalah agar dalam aktivitas ekonominya ummat manusia tidak meninggalkan nilai-nilai agama khususnya agama Islam. Zakat yang bernilai ibadah kepada Allah akan semakin meningkatkan hakikat manusia sebagai makhluk spiritual.

\section{METODE}

Artikel ini merupakan jenis penelitian kajian pustaka dengan mencari referensi teori yang relevan dengan kasus atau permasalahan yang ditemukan yang bisa didapat dari berbagai sumber jurnal, buku, dokumentasi, internet dan pustaka. Referensi teori yang diperoleh dengan jalan penelitian study literatur dijadikan sebagai fondasi dasar dan alat utama bagi praktek penelitian ditengah lapangan.

Data-data yang sudah diperoleh kemudian dianalisis dengan metode analisis deksriptif. Metode analisis deskriptif dilakukan dengan cara mendeskripsikan faktafakta yang kemudian disusul dengan analisis untuk memberikan pemahaman dan penjelasan secukupnya.

\section{HASIL DAN PEMBAHASAN}

Ketamakan dan Eksploitasi. Salah satu bentuk sifat manusia adalah rakus dan tamak dengan alam, maupun dengan manusia lainnya. Penguasaan sumber daya alam oleh sekelompok orang memunculkan konflik lingkungan berkepanjangan mulai dari diskriminasi, ketidakailan, dan marjinalisasi kepentingan masyarakat Perilaku eksploitasi sumber daya alam akhirnya memunculkan kelangkaan dan kerusakaan lingkungan yang tinggi.

Di Indonesia, sumber daya alam dikuasi oleh kelompok tertentu dan investor asing yang menimbulkan meningkatnya devisa negara. Tetapi disisi lain mempunyai masalah yang bersamaan yaitu marjinalisasi suku - suku masyarakat pedalaman, dan menurunnya ekonomi local. Hanya masyarakat tertentu yang menikmati keuntungan dari pemanfaatan sumber daya alam dan kerugian yang dirasakan oleh masyarakat local.Kepentingan ekonomi nasional memang memperoleh manfaat dari devisa hasil sumber daya alam tetapi daya hidup masyarakat local mengalami penurunan. Keuntungan - keuntungan hanya dinikmati segelintir konglomerat dan orang yang bekerja sama dengannya.

Eksploitasi sumber daya alam "kerakusan" nyata memunculkan sikap individualis yang artinya tidak mau menanggung kerusakan yang diperbuat (disebut not in my back yard). hal ini sangat merugikan masyarakat lain pasanya hanya mau mengambil sumber daya alam tetapi menimbulkan permasalahan di kemudian hari misalkan tanah longsor. Dalam surah Al- Baqarah ayat 96 yang artinya "Dan sungguh kamu akan mendapati mereka, manusia yang paling tamak kepada kehidupan (di dunia), bahkan (lebih tamak) dari orang -orang musyrik. Masing -masing mereka ingin agar diberi umur seribu tahun, padahal umur Panjang itu sekali -kali tidak akan menjauhkannya daripada siksa. Allah Maha Mengetahui yang mereka kerjakan".

Sudah jelas bahwa Allah SWT sangat benci kepada orang yang serakah karena akan mengakibatkan lalai dalam beribadah kepada Allah. Orang yang serakah akan mempunyai sifat cinta dunia, tidak mempunyai rasa tolong menolong, dan lupa akan qadha dan qadhar Allah. Dengan dalih meningkatkan kesejahteraan dan mencari kenikmatan hidup hanya untuk keluarganya, mereka mengaibakan kepentingan bersama dam memunculkan krisis lingkungan hidup padahal hal ini sudah dingatkan dalam surah Ar-Ruum ayat 41.

Hakikat manusia dalam pandangan Islam. Allah telah memaparkan secara jelas tentang hakikat manusia serta kewajibannya di dalam Al-Qur'an. Hakikat manusia yang berasal dari Allah-lah yang seharusnya menjadi pijakan manusia dalam melaksanakan aktivitas. Fidiana dalam buku akuntansi syariah menjelaskan bahwa mengenali hakikat diri sendiri merupakan hal yang sangat penting karena memiliki kaitan terhadap bagaimana kita memandang dan memaknai hidup dan kehidupan yang akan berpengaruh pada cara kita berinteraksi dengan orang lain dan cara menjalani kehidupan di muka bumi (Adesy, 2016). 
Salah satu hakikat manusia yang paling mendasar adalah manusia sebagai hamba Allah. Dalam surah ad-dzariyat ayat 52 Allah menjelaskan "Tidaklah aku ciptakan jin dan manusia, supaya mereka menyembah kepadaku". Manusia diwajibkan mengabdi dan taat kepada Allah, bentuk pengabdian manusia tidak hanya terbatas pada ucapan dan perbuatan tapi juga keikhlasan hati (Khasinah, 2013). Implikasi dari kesadaran manusia sebagai hamba Allah yang selalu berpedoman pada Al-Qur'an dan hadits dengan cara menjalankan segala perintah-Nya dan menjauhi segala larangan-Nya.

Manusia juga dikatakan sebagai khalifah yang diberikan amanah dalam melestarikan alam dengan memanfaatkan sumber daya alam yang dianugerahi Allah secara adil. Manusia sebagai khalifah dijelaskan Allah dalam beberapa surah diantaranya yaitu surah Al-Baqarah ayat 30 dan surah As-Shad ayat 20. Pada surah As-Shad ayat 20, Allah menjelaskan " Hai Daud, sesungguhnya Kami menjadikan kamu khalifah (penguasa) di muka bumi, maka berilah keputusan di antara manusia dengan adil dan janganlah kamu mengikuti hawa nafsu. Karena ia akan menyesatkan kamu dari jalan Allah..." Ayat tersebut menjelaskan tindakan manusia yang sangat bertentangan dengan konsep manusia yang dibentuk oleh ekonomi kapitalis dimana manusia untuk meningkatkan kekayaan dengan menafaatkan sumber daya sebanyak-banyaknya.

Dengan menyadari diri sebagai hamba Allah dan khalifah di muka bumi akan membentuk manusia dalam beraktivitas termasuk aktivitas ekonomi selalu menghadirkan Allah dan menjalankan aktivitas yang sesuai dengan syariat Islam. Dalam hal ini maka manusia akan menghindari sifat yang tamak akan kekayaan dunia, eksploitasi sumber daya secara berlebihan serta aktivitas ekonomi yang mengandung haram seperti riba. Kekayaan yang dihasilkan manusia juga akan disalurkan kepada fakir miskin sesuai dengan perintah Allah SWT yaitu melalui zakat.

Diskursus sumber utama dalam kesejahtraan semesta: Pajak atau Zakat?. Di era modern ini, pajak dijadikan sebagai pilar utama dalam pertumbuhan ekonomi suatu negara. Pertumbuhan ekonomi diartikan sebagai kenaikan kapasitas suatu negara dalam jangka panjang dalam menyediakan barang ekonomi untuk masyarakatnya (Sasana, 2009). Pertumbuhan ekonomi juga sering dikaitkan dengan produktivitas dimana produktivitas ini berefek standar kehidupan.

Todaro (2003) memaparkan bahwa dalam pertumbuhan ekonomi terdapat tiga komponen yang mendasarinya. Pertama, akumulasi modal yang meliputi seluruh investasi pada tanah, peralatan, modal maupun sumber daya manusia. Kedua, pertumbuhan penduduk terkait pertumbuhan jumlah angkatan kerja. Dan terakhir adalah kemajuan teknologi yang berkaitan dengan cara-cara yang digunakan dalam melakukan pekerjaan. Berdasarkan tiga komponen tersebut, dapat ditarik kesimpulan tujuan pajak untuk pertumbuhan ekonomi hanya sedikit sekali menaruh perhatian pada kesejahtraan semesta bahkan dalam ekonomi klasik, modal memainkan peran penting dalam pertumbuhan ekonomi. Sehingga jika kita menelusuri sebaran pajak dalam suatu negara, maka tidak akan terlalu mencengangkan jika ditemukan hasil pajak banyak digunakan dalam investasi daripada dalam pemberantasan kemiskinan.

Kajian selanjutnya tentang pajak adalah dari sisi hukum yang berlaku di pajak. Berbeda dengan zakat yang ketentuaan dalam pemungutan dan penyalurannya telah diatur oleh Allah SWT dalam Al-Qur'an dan hadits, hukum dalam pajak ditentukan oleh pemerintah dalam peraturan perundang-undangan (Andriani, 2013). Dalam hal ini, zakat lebih dapat dipercaya dari segi hukumnya karena sistemnya langsung diatur oleh Allah, Sang Pemilik Semesta.

Sumber utama pendapatan di dalam suatu pemerintah negara Islam pada periode klasik serta di negara -negara Islam pada umumnya adalah zakat, yang notabenennya merupakan salah satu rukun Islam. Setelah solat, zakat dipandang sebagai bentuk kewajiban keagamaan terpenting yang digunakan yang dikenakan kepada umat islam. Zakat berpengaruh besar terhadap berbagai sifat dan cara kepemilikan harta benda (kekayaan). 
Tanpa merinci lebih jauh tentang zakat, zakat berfungsi sebagai membangun negara. Karena mendayagunakan semua bentuk kekayaan yang ada. Tidak seperti seperti dalam halnya pajak modern, pengaturan zakat lebih mudah. Pelaksanaan pemungutan zakat secara semestinya, dapat menghapus tingkat perbedaan kekayaan yang sangat mencolok, serta sebaliknya dapat menciptakan redistribusi yang merata, disamping dapat pula membantu mengekang laju inflasi. Selain perkembangan tak menentu dari peredaran mata uang di dalam negeri, kekurangan barang dan kecepatan peredaran uang, distribusi kekayaan yang tidak tepat merata dapat pula mengakibatkan timbulnya laju inflasi da kehancuran pasar. Penangan yang tepat akan zakat secara bertahap dapat menciptakan kondisi keseimbangan tata ekonomi seperti diinginkan.

Kita tahu islam muncul sebagai system nilai yang mewarnai perilaku ekonomi umat islam dengan menawarkan zakat yang memiliki potensi strategis dalam mengurangi kemiskinan melalui distribusi harta.

Tabel 1. Data Pengumpulan ZIS Tahun 2013-2017

\begin{tabular}{ll}
\hline Tahun & Penerimaan pajak (milyar Rp) \\
\hline 2013 & $2.639,00$ \\
2014 & $3.300,00$ \\
2015 & $3.650,00$ \\
2016 & $5.107,29$ \\
2017 & $6.224,37$ \\
\hline
\end{tabular}

Sumber: Badan Amil Zakat Nasional, Statistik Zakat Nasional 2017

Zakat dari segi literaturnya berasala dari Bahasa Arab, terdiri dari atas huruf $z a$, kaf, dan wawu. Karena akan menimbulkan kesulitan membaca, maka wawu diganti dengan ta' al -marbuthah sehingga dibaca zakat. Secara etimologi, kata zakat berarti bersih, bertambah, dan bertumbuh. Jika dikatakan bahwa tanaman itu zakat artinya ia tumbuh dan bertambah tumbuhannya. Jika tanaman tersebut tumbuh tanpa cacat maka zakat berarti bersih. zakat mampu menjadi pengingat juga bahwa harta yang diperoleh oleh hasil usaha manusia bukannlah menjadi milik mutlak baginya, sebab disitu terdapat hak orang lain. Zakat bukanlah derma atau sedekah biasa, ia adalah iuran wajib yang harus diberikan kepada penerima zakat. jadi perbuatan orang orang kaya dalam mengekuarkan hartanya kepada yang kurang mampu bukannlah belas kasihan tetapi kewajiban.

Dalam hokum islam melaksanakan kewajiban mendapatkan pahala dan meninggalkan kewajiban mendapatkan dosa. Hal ini sesuai dengan firman Allah dalam surat ali Imran ayat 180 yang artinya "sekali -kali janganlah orang -orang bakhil dengan harta yang Allah berikan kepada mereka dari karunianya menyangka, bahwa kebakhilan itu baik bagi mereka. Sebenarnya kebakhilan buruk bagi mereka, harta yang mereka bakhilkan itu akan dikalungkan kelak dilehernya dihari kiamat"

Zakat termasuk kebaikan -kebaikan Islam yang datang membawa persamaan hak, kasih sayang, tolong menolong, dan memotong tiap jalan keburukan yang dapat mengancam keutamaan, keamanan, dan kelapangan dari berbagai sendiri, kemaslahatan dunia dan akhirat. Kewajiban berzakat ini sebagai perwujudan keimanan kepada Allah, menyukuri nikmatnya menumbuhkan akhlak mulia dengan rasa kemanusiaan yang tinggi, menumbuhkan ketenangan hidup, menghilangkan sifat kikir, rakus, dan materialistic atau mencintai harta.

Islam memberikan suatu konsep yang jelas mengenai harta, karena harta mempunyai nilai strategis. Konsep harta atau kekayaan dalam islam bukan sebagai asset semata namun sebagai pemenuhan kebutuhan hidup bukan untuk memenuhi kebutuhan manusia yang tidak terbatas. Oleh karena itu islam mengatur bagaimana manusia memanfaat harta sebaik -baiknya tidak hanya kepentingan dunia tetapi juga dipertanggung jawabkan di akhirat.

Mengingat begitu pentingnya pembahasan tentang pengembangan ekonomi, misalnya zakat yang telah menawarkan nilai -nilai perekonomian dan kesejahteraan umum dalam membangun kehidupan masyarakat. Zakat sebagai pengatur dalam mempergunakan dan mengelola bumi seisinya manusia harus menyessuaikan dengan 
ketentuan agama, seperti halnya tidak tamak, tidak boleh memperkaya diri, dengan membabi buta, tidak boleh berbuat kerusakan alam.

Melihat banyaknya hikmah dalam berzakat, maka zakat membenahi sikap ketamakan karena mempunyai dimensi pertama, dimensi individu (menginginkan perubahan individu), tercermin dalam penyucian diri manusia dari sifat buruk seperti rakus dan kikir, kedua dimensi social yakni mengubah tatanan social untuk membangun budaya tanggung jawab social dan kesahteraan bersama. Dimensi tersebut dapat terlihat melalui manfaat atau hikmah yaitu;

Pertama, bagi pelakunya dapat mengikis habis sifat -sifat kikir, bakhil, rakus, dan tamak yang didalam dirinya dan melatih memiliki sifat -sifat deramwan, mengantarkannya mensyukuri nikamt Allah SWT. Sehingga pada akhirnya ia dapatkan mengembangkan dirinya, membersihkan harta yang kotor karena di dalam harta yang dimilik terdapat hak orang lain, menumbuhkan kekayaan, terhindar dari siksa atau ancaman Allah.

Kedua, bagi penerima, membersihkan perasaan sakit hati, benci, dan dendam terhadap golongan yang lebih berada.

Ketiga, bagi pemerintah dapat menunjang keberhasilan pelaksanaan program pembangunan dala meningkatkan kkesejahteraan warganya, mengurangi beban pemerintah dalam mengatasi kasus -kasus kecemburuan social.

Dari ketiga hikmah tersebut, mengandung dimensi nilai: pertama, dimensi spriritual, yakni bertambahnya keimanan kepada Allah. kedua dimensi social, yaitu terciptanya masyarakat yang memiliki solidaritas tinggi, sehingga melahirkan kecintaan dan kepedulian terhadap sesama dan kekeluargaan antar umat akan semakin tampak. dan ketiga dimensi ekonomi, yakni terciptanya masyarakat Makmur dan sejahtera. Pada hakikatnya dengan terlaksananya hikma zakat maka tercipta masyarakat yang Makmur, tentram adil, dan sejahtera.

\section{SIMPULAN}

Penerapan pajak sebagai sumber utama dalam perekonomian suatu negara menunjukkan bahwa pajak yang berorientasi pada pertumbuhan ekonomi belum mampu meminimalisir kesenjangan ekonomi yang terjadi pada masa rakyat, mengingat bahwa pertumbuhan ekonomi yang menjadi tujuan pajak hanyalah diukur dari akumulasi modal, pertumbuhan penduduk, dan kemajuan teknologi sedangkan kesejahtraan semesta hanya mendapat perhatian yang sangat sedikit. Sehingga diperlukan suatu sistem yang dapat menjawab permasalahan-permasalahan ekonomi dan kemiskinan yang hampir diderita oleh suatu negara. Islam dalam pemerataan sosial ekonomi melalui zakat. Sebagai hamba Allah dan khalifah di bumi, maka sudah menjadi kewajiban bagi manusia dalam menyalurkan kekayaan yang dititipkan Allah padanya. Dengan prinsip distribusi kekayaan yang dapat mencegah dari sifat ketamakan, menghapus kemiskinan dan mencegah penumpukan serta bernilai ibadah di sisi Allah, sudah seharusnya zakat menjadi prioritas utama yang dipilih oleh ummat manusia dalam menyisihkan harta miliknya dan dijadikan sebagai sumber utama oleh negara khususnya negara yang mayoritas penduduknya beragama Islam.

\section{DAFTAR PUSTAKA}

Adesy, Fordebi. (2016). Akuntansi Syariah: Seri konsep dan aplikasi ekonomi dan bisnis Islam. Jakarta: PT. RajaGrafindo

Aibak, Kutbuddin. (2018). "Zakat Dalam Prespektif Maqashid Al- Syariah", Jurnal Ahkan, (3)2: 199-218.

Andriani. Fitha Fathya. (2013). Zakat sebagai Pengurang Pajak Penghasilan pada Badan Amil Zakat. JRAK Vol. 4 No. 1

Bahri, Andi. (2016). "Zakat Sebagai Instrumen Pembanguna Ekonomi Kesejahteraan Ummat', Jurnal Studi Ekonomi dan Bisnis Islam: Li Falah, (I)2.

Herdianto, Ahmad Wahyu. (2011). Peran Negara Dalam Mengoptimalkan Zakat Di Indonesia, Jurnal Hukum dan Syariah, 2(1): 103- 116

Khasinah, Siti. (2013). Hakikat Manusia Menurut Pandangan Islam. Jurnal Ilmiah DIDAKTIKA Vol.XXI No. 2 
Ma'arif, M. Jauharul. (2018). Nilai -Nilai Pendidikan Dalam Pelaksanaan Zakat, Jurnal At Tuhfah: Jurnal Keislaman. 7(1).

Nuruddin, M. (2014). Transformasi Hadist - Hadist Zakat Dalam Mewujudkan Ketangguhan Ekonomi Pada Era Modern, Ziswaf, 1(2).

Patmawati Ibrahim. (2008). Pembangunan Ekonomi Melalui Agihan Zakat: Tinjauan Empirikal', Jurnal Syariah, 16(2): 223-244.

Qur'an, Amanah Aida. (2017). Sumber Daya Alam Dalam Pembaguan Berkelanjutan Prespektif Islam. Jurnal Ekonomi Islam: El- Jizya, 5(1).

Safitri, Junaidi. (2017). Implementasi Konsep Zakat Dalam Al-Quran Sebagai Upaya Mengentasakan Kemiskinan Di Indonesia', Jurnal Studi Islam: Mukaddimah, 2(1).

Sodiq, Amirus. (2015). Konsep Kesejateran Dalam Islam. Jurnal Equilibrium, 3(2).

Todaro, Michael, Smith. (2003). Economic Development, Eighth Edition. United Kingdom: Pearson Education Limited.

Uyun, Qurratul. (2015). Zakat, Infaq, Shadaqah, dan Wakaf ASebagi Konfigurasi Filantropi Islam. Jurnal IslamUNA, 2(2).

Yusuf al-Qardhawi. (1995). Daur al-Qiyam wa al-Akhlak fi al-Iqtishadi al-Islami, Kairo: Maktabah Wahbah 